IJBPAS, November, 2021, 10(11): 3959-3967

ISSN: $2277-4998$

International Journal of Biology, Pharmacy

and Allied Seiences (IJBPAS)

'A Bridge Betuben Caboratory and QRendo'

WwW.ijbpas.com

BIOCHEMICAL AND MINERAL COMPOSITION OF FRESHWATER CYPRINID

FISH PUNTIUS SOPHORE FROM MUDAGODU TANK OF CHIKMAGALUR

DISTRICT, KARNATAKA

\title{
DHANANJAYA SG
}

Assistant Professor, Department of Zoology, Government Science College, Chitradurga-577501, Karnataka, India

*Corresponding Author: Dr. S.G. Dhananjaya: E Mail: dhananjayazoo@gmail.com

Received $16^{\text {th }}$ Jan. 2021; Revised 15 ${ }^{\text {th }}$ Feb. 2021; Accepted $14^{\text {th }}$ March 2021; Available online $1^{\text {st }}$ Nov. 2021

https://doi.org/10.31032/IJBPAS/2021/10.11.5711

\section{ABSTRACT}

The knowledge of the biochemical and mineral composition of food is of utmost importance to know its nutritional value of fishes. In the present era the peoples are very precautious about health and diet. The fishes are known for rich source of protein. Fish contains almost all the nutrients required for good quality health. An attempt was made to estimate the biochemical and mineral compositions of body muscles of Puntius sophore collected from Mudagodu tank of Karnataka. The evaluation of biochemical composition included the moisture, fat, protein, ash and carbohydrate contents. Along with these nutrients, few minerals like potassium, phosphorous, pagnesium, calcium, zinc and copper were also evaluated in this study. The fish samples collected from different sites of the tank exhibited fluctuations in nutritional values.

Keywords: Puntius sophore, Nutritional Value, Biochemical Composition, Minerals, Mudagodu tank

\section{INTRODUCTION}

The fish is being consumed by several rich source of essential nutrients, animals and humans as an important food source in their everyday diet. The fishes are a comparatively economical and easily available as well. These nutrients from 
fishes provide necessary strength to fight ailments and nutritional security [1]. The fish nutrients include oils, a rich source of polyunsaturated fatty acids, few minerals like calcium, zinc, iodine, iron, vitamins $\mathrm{A}$ and $\mathrm{C}$, etc. It is healthy food. Even in the small and local species also has enough nutritional components that compensate for the regular diet deficiencies. In the present world, where food availability and affordability are a challenge, fishes can be an easy and suitable alternative.

Greater part of the nutritionist recommended that humans should eat fish every day [2-5]. An rising amount of evidence suggest that fish meat and fish oil contains maximum amount of polyunsaturated fatty acid that are decreasing the cholesterol level to prevent coronary heart diseases $[6,7]$. Fish meal can reduce the risk of dementia and Alzheimer's diseases [8].

Proximate compositions of fish tissue are interest in relation to food values of fish and evaluate their physiological requirements at different periods of life. Many researchers have studied the depletive effects of maturation and spawning in the chemical composition of fish [9-13].

The variations in biochemical and mineral variations of Cyprinid fish have not been given much attention of Puntius sophore of Mudagodu tank, Karnataka. Hence, keeping in view of the importance of fish, an attempt has been made to study the above aspect.

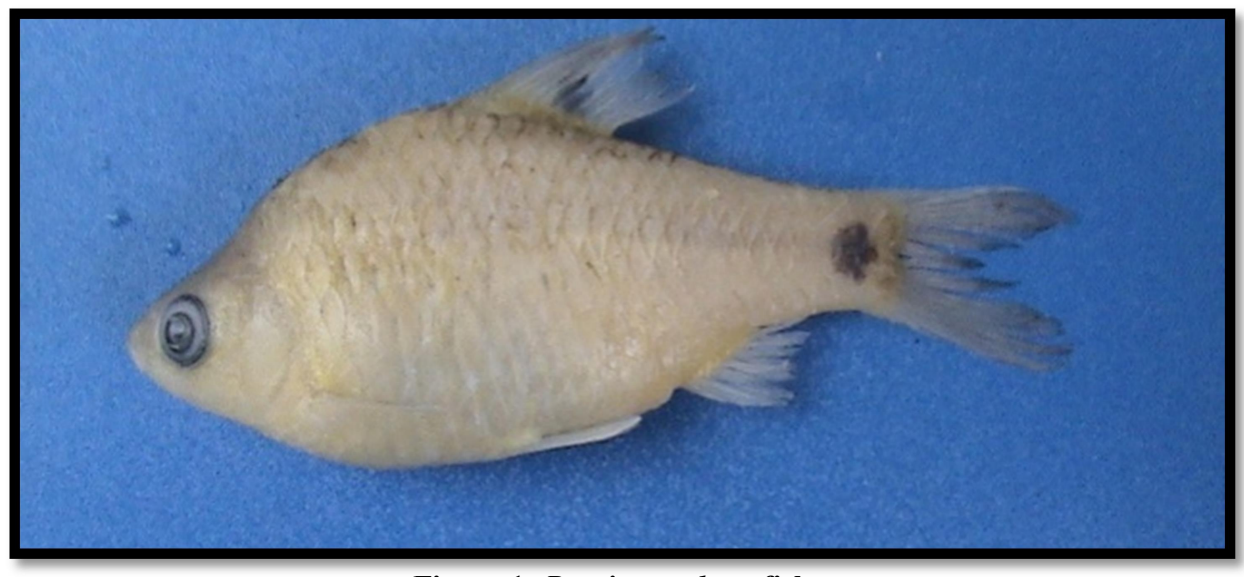

Figure 1: Puntius sophore fish

\section{MATERIALS AND METHODS}

\section{Proximate Composition of Fish}

Fresh specimens of Puntius sophore obtained from Mudagodu tank were brought to the laboratory in iced condition. Later, washed and then their total length and weight were recorded. Further, muscle tissue was removed and utilised for the estimation of protein, lipid and carbohydrate [14-16]. 
The moisture content was estimated by AOAC [17] method. For the estimation of protein, the biuret method as given by Raymont et al [14] was followed. For this, 30 mg of fresh tissue samples were removed and homogenised with $1 \mathrm{ml}$ of distilled water. Later, $4 \mathrm{ml}$ of biuret reagent was added to it in two installments of $2 \mathrm{ml}$ each. They were then centrifuged for 30 minutes at $3000 \mathrm{rpm}$ for 15 minutes. The clear supernatant fluid was read at $540 \mathrm{~nm}$ using UV-VIS spectrophotometer and the protein was estimated using the values of optical density as follows:

Protein $(\%)=18.44 \times$ optical density / Weight of tissue (mg) X100

To estimate lipid, the method given by Bligh and Dyer [15] was followed. In this method, a mixture of chloroform and methanol (2: 1 $\mathrm{V} / \mathrm{V}$ ) was used. About $1 \mathrm{gm}$ of tissue was first ground using a pestle and mortar with about $10 \mathrm{ml}$ of distilled water. The pulp was then transferred to a conical flask $(250 \mathrm{ml}$ capacity) and $30 \mathrm{ml}$ of chloroform methanal mixture was added to it and mixed well. This was kept overnight at room temperature in dark condition for complete extraction of lipid. At the end of this period, $20 \mathrm{ml}$ of chloroform and $20 \mathrm{ml}$ of water were added. The top methanol layer was discarded and the lower layer was collected free of thick pasty interphase by sucking out with a fine capillary tube. The collected layer, after the extraction, was taken in a preweighed beaker and carefully evaporated. The beaker with sample was kept covered with a dark paper to protect from light to avoid lipid polymerisation and decomposition. When the residue was free from solvent mixture, the weight was determined again. The difference in weight gave the weight of lipid. The results were expressed in terms of weight in milligrams of total lipid per $100 \mathrm{mg}$ of fresh tissue.

Carbohydrate was estimated by phenolsulfuric acid method as given by Dubois et al [16]. To $20 \mathrm{mg}$ of fresh tissue sample, $1 \mathrm{ml}$ of distilled water was added, followed by the addition of $1 \mathrm{ml}$ of $5 \%$ phenol and $5 \mathrm{ml}$ concentrated sulphuric acid. After 30 minutes, the sample was read at $490 \mathrm{~nm}$ in UV-VIS spectrophotometer. The value of optical density was utilised to estimate the carbohydrate as:

Carbohydrate $(\%)=0.1 \times$ optical density/ Weight of tissue (mg) x100

The ash content of the sample was determined by heating, the incinerated sample in porcelain crucibles in a muffle furnace maintained at $5500 \mathrm{C} \pm 100 \mathrm{C}$, for 5 hrs [17]. 


\section{Minerals Estimation}

To analyse the minerals, entire fish samples were used. The micronutrients like zinc and copper were evaluated by the Atomic Absorption Spectrophotometer using a modified method [18].

\section{Statistical Analysis}

One way-ANOVA and Post Hoc Tukey HSD test were calculated for biochemical and mineral components by using statistical software of socscistatistics.com to know the significance among the components.

\section{RESULTS AND DISCUSSION}

\section{Biochemical and Mineral Composition}

Figure 2 depicts the biochemical data of Puntius sophore. Protein level deviated 18.5 to $23.7 \%$. While, moisture content fluctuated from 69.8 to $75.3 \%$. However, fat, ash and carbohydrate levels ranged in between 1.0 and $2.3 \%$.

As in Figure 3, potassium content ranged from 650 to $698 \mathrm{mg} / 100 \mathrm{gm}$. Calcium and magnesium levels varied from 120-155 and $110-139 \mathrm{mg} / 100 \mathrm{gm}$ respectively. Phosphorus in the fish deviated from 242 to 248 $\mathrm{mg} / 100 \mathrm{gm}$. Trace metals like zinc and copper ranged between 18-24 mg/100gm and 3.9-4.2 $\mathrm{mg} / 100$ gm respectively.

The body composition of fish is known to be influenced by the chemical content of the diet [19]. The biochemical composition of Oreochromis mossambicus populations from 9 reservoirs of Sri Lanka were evaluated by De Silva et al [20] when they found that the mean percentage of protein, total lipid and carbohydrate content were $24.18 \%, \quad 7.91 \%$ and $22.34 \%$ respectively. Middle part of the muscle of Tor khudree fish had low lipid content as reported by Nair and Radha Krishnan [21]. Correspondingly, Iqbal and Choudhary [22] have noticed low ash in Cyprinus carpio and high in Labeo dero . Norman [23] opined that period of gonads may play a great role in the biochemical composition of a fish.

Kiran [24] studied the biochemical constituents of raw and dried specimens of the freshwater fish Salmophasia untrahi from Bhadra reservoir, Karnataka. The proximate composition of dried fish showed maximum and minimum occurrence during different seasons is attributed to variations in feed, water quality, stage of gonads, spawning and breeding activity.

The maximum and minimum occurrence of moisture, protein, lipid/fat, carbohydrate and ash contents during different seasons may be attributed to variations in feed intake (Plankton), water quality, stage of gonads and spawning. Many researchers have observed the depletive effects of maturation and spawning on the 
chemical composition of fishes $[9,10,25-$ 27].

Minerals are necessary for metabolism in human beings [28]. Deficiency of essential minerals leads to enzyme-mediated metabolic disfunctions and results in organ malfunctions, chronic diseases and ultimately death [29]. The concentration of minerals are shown in Figure 3. Sodium, potassium, calcium, zinc magnesium, copper, were detected in fresh P. sophore. High level of potassium and Phosphorus contents were found in fresh $P$. sophore.

\section{Statistical Analysis}

Table 1 depicts One way ANOVA data.

\section{Post Hoc Tukey HSD (beta)}

The Tukey's HSD (honestly significant difference) procedure facilitates pair wise comparisons within your ANOVA data. The F statistic (above) tells whether there is an overall difference between sample means. Tukey's HSD test determine the various pairs of means - if there is a significant difference. The Q indicates a significant result. Tukey's HSD is appropriate if the F-ratio has not reached the significance (Table 2).

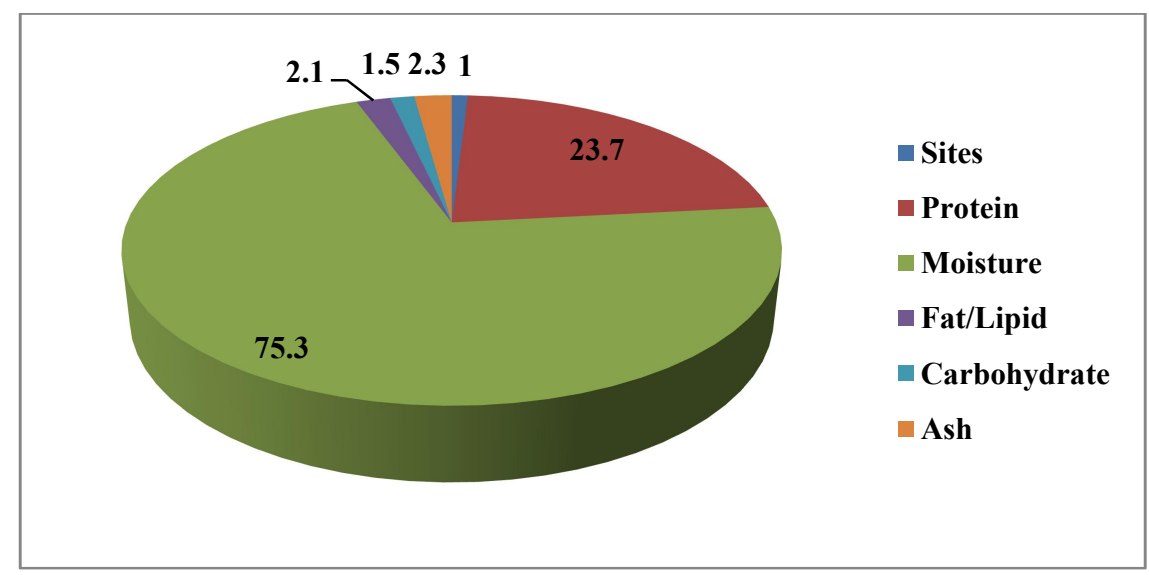

Figure 2: Biochemical composition (\%) of Puntius sophore from Mudagodu tank

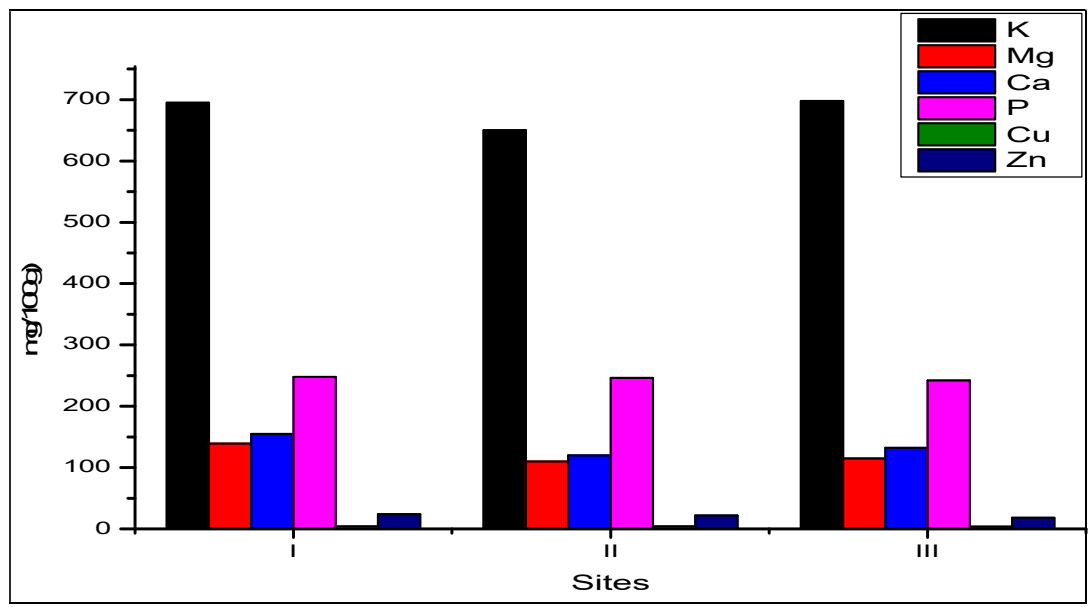

Figure 3: Mineral composition (mg/100g) of Puntius sophore from Mudagodu tank 
Table 1: One way ANOVA data

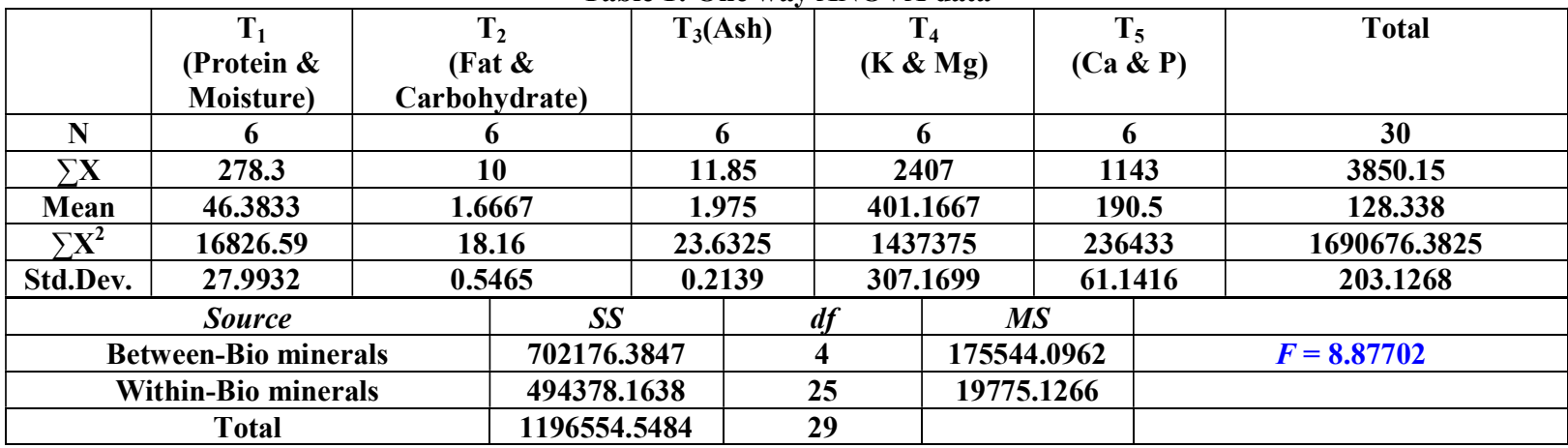

The f-ratio value is 8.87702 . The $p$-value is .000133 . Significant at $p<.05$

Table 2: Post Hoc Tukey HSD results

\begin{tabular}{|c|c|c|c|}
\hline \multicolumn{2}{|c|}{ Pair wise Comparisons } & $\mathrm{HSD}_{.05}=238.4448$ & $Q_{.05}=4.1534 \quad Q_{.01}=5.1439$ \\
\hline$T_{1}: T_{2}$ & $\begin{array}{c}M_{1}=46.38 \\
M_{2}=1.67\end{array}$ & 44.72 & $Q=0.78(p=.98083)$ \\
\hline$T_{1}: T_{3}$ & $\begin{array}{c}M_{1}=46.38 \\
M_{3}=1.98\end{array}$ & 44.41 & $\mathrm{Q}=0.77(p=.98132)$ \\
\hline $\mathbf{T}_{1}: \mathbf{T}_{4}$ & $\begin{array}{c}M_{1}=46.38 \\
M_{4}=401.17\end{array}$ & 354.78 & $Q=6.18(p=.00164)$ \\
\hline $\mathrm{T}_{1}: \mathrm{T}_{5}$ & $\begin{array}{c}M_{1}=46.38 \\
M_{5}=190.50\end{array}$ & 144.12 & $Q=2.51(p=.40944)$ \\
\hline $\mathbf{T}_{2}: \mathbf{T}_{3}$ & $\begin{array}{l}M_{2}=1.67 \\
M_{3}=1.98\end{array}$ & 0.31 & $Q=0.01(p=.00000)$ \\
\hline $\mathbf{T}_{2}: \mathbf{T}_{4}$ & $\begin{array}{c}M_{2}=1.67 \\
M_{4}=401.17\end{array}$ & 399.50 & $Q=6.96(p=.00041)$ \\
\hline $\mathbf{T}_{2}: \mathbf{T}_{5}$ & $\begin{array}{c}M_{2}=1.67 \\
M_{5}=190.50\end{array}$ & 188.83 & $\mathrm{Q}=3.29(p=.17006)$ \\
\hline $\mathbf{T}_{3}: \mathbf{T}_{4}$ & $\begin{array}{c}M_{3}=1.98 \\
M_{4}=401.17\end{array}$ & 399.19 & $Q=6.95(p=.00041)$ \\
\hline $\mathbf{T}_{3}: \mathbf{T}_{5}$ & $\begin{array}{c}M_{3}=1.98 \\
M_{5}=190.50\end{array}$ & 188.53 & $\mathrm{Q}=3.28(p=.17123)$ \\
\hline $\mathbf{T}_{4}: \mathbf{T}_{5}$ & $\begin{array}{l}M_{4}=401.17 \\
M_{5}=190.50\end{array}$ & 210.67 & $Q=3.67(p=.10191)$ \\
\hline
\end{tabular}

\section{CONCLUSION}

Present study will provide a baseline data on proximate composition of P.sophore in Mudagodu tank of Karnataka. This fish has a significant source of protein and mineral elements and they will provide good nutrition to the people of the region to the rural poor people. This fish diet helps to prevent malnutrition and improving microelements deficiencies. The findings could be useful to the people of this region regarding the nutritional importance of using this fish.

\section{REFERENCES}

[1] Mohanty B P, Ganguly S, Mahanty A, Mitra T, Patra S, Karunakaran D, Mathew S, Chakraborty K, Paul BN., Sarma D, Dayal S., Singh S, Ayyappan S. Fish in Human Health and Nutrition. In B.P. Mohanty (ed.) Advances in Fish Research, Narendra 
Publishing House, New Delhi, 2019: 189-218.

[2] Blanchet C E, Dewailly P, Ayotto S, Bruneau O, Receveur, Holub BJ. Contribution of selected traditional and market foods to the diet of Nunavik Inuit women. Can. J. Diet Pract. Res. 2000; 61: 50-59.

[3] Nestel PJ. Fish oil and cardiovascular disease: Lipids and arterial function. Am.J.Clin.Nutr.2000; 71: 228S-231S.

[4] Balk E, Chung M, Lichtenstein A, Chew P, Kupelnick B. Effect of omega-3 fatty acids on cardiovascular risks factors and intermediate markers of cardiovascular disease. Agency Healthcare Res. Qual. (US). Report, 2004; No.: 04-E0102. http:/www.ahrg.gov/downloads/pub/ evidence/pdf/o3c ardrisk/o3cardrisk.pdf

[5] Sanjrambam Sanayaima Devi, Wangkheimayum Vidyarani Devi. To Study the Difference of Proximate Composition during Pre and PostMonsoon Season of Esomus danricus and Puntius sophore. International Journal of Science and Research 2016; Volume 5 Issue 3: 423-425.

[6] Nordoy A, Marcholi R, Arnesen H, Videbaek J.N-3 polyunsaturated fatty acids and cardiovascular diseases. Lipids 2001; 36: S127-S129.

[7] Turkmen A ,Turkmen M, Tepe Y, Akyurt I. Heavy metals in three commercially valuable fish species from iskenderum bay, northern east Mediterranean sea, Turkey. Food Chem. 2005; 91: 167-172.

[8] Grant WB. Dietary linked to Alzheimer's disease. alzeimer's. Dis. Rev. 1997; 2: 42-55.

[9] Appa Rao T. Fat and Water Contents of the Muscle and Ovary During the Maturation Cycle of pseudosciaena Aneus (Block) and Johnius Carutta (Bloch) Indian J. Fish. 1967; 14: 293 297.

[10] Pandey BN, Datta Munshi JS, Choubey BJ, Pandey PK. Seasonal variation in body composition in relation to breeding cycle of an Airbreathing fish, Heteropneustes fossilis (Bloch).J. Inland Fish. Soc. India 1976; 8: 91-95.

[11] Piska RS, Prasad RM. Seasonal variation in biochemical composition of reproductive tissue in relation to breeding cycle of the carp minnow. Salmostoma bacaila (Ham) from Himayathsagar, 
Hyderabad. Comp. Physiol. Ecol.1991; 16(2): 69-71.

[12] Kiran BR, Puttaiah ET. Biochemical composition of Chela untrahi from Bhadra reservoir, India, Geobios, 2005; 32: 93-95.

[13] Ashashree HM, Venkateshwarlu M,Sayeswara HA. Seasonal changes of protein in the tissues of male catfish Mystus cavasius (ham) in Bhadra reservoir, Karnataka, India. International Journal of Applied Biology and Pharmaceutical Technology 2013; 4(4); 264-267.

[14] Raymont TEC, Austin J, Linford E. Biochemical studies on Marine zooplankton. The biochemical composition of Neomysis integer. J. Cons. Perm. Int. Explore Sci.1964; 28: 354-363.

[15] Bligh EG, Dyer WJ. A rapid method of total lipid extraction and purification. Can. J. Biochem. Physiol. 1959; 37(8): 911-917.

[16] Dubois M, Gilles KA, Hamilton JK, Rebers PA, Smith. Colorimetric method for determination of sugars and related substances. Analy. Chem.1956; 28: 350-356.

[17] AOAC. Official methods of analysis, $12^{\text {th }}$ Ed. Association of official analytical chemists. Washington.1975, D.C.

[18] Cresser MS, Parson JW. Sulphuric perchloric acid digestion of plant material for the determination of $\mathrm{N}$, $\mathrm{P}, \mathrm{K}, \mathrm{Ca}$ and $\mathrm{Mg}$. Anal. Chemi. Acta. 1979; 109: 431-436.

[19] Zeitler MH, Kirchgessner M, Schwarz FJ. Effect of different protein and energy supplies on carcass composition of carp (Cyprinus carpio L.). Aquaculture 1984; 36: 37-48.

[20] De Silva SS, Perera MK, Maitipe P. The composition, nutritional status and digestibility of Sarotherodon mossambicus from nine man-made lakes in Sri Lanka. Environ. Biol. Fish.1984a; 113: 205-219.

[21] Nair VM, Radha Krishnan KV. Regional variations in lipid and moisture content of Tor khudree muscle. In: The First Indian Fisheries Forum, Proceedings. (Ed. Mohan Joseph, M.). Asian Fisheries Society, Indian Branch, Mangalore, 1988: 89-90.

[22] Iqbal SE, Chowdhary SK. Biochemical composition of few cyprinid fishes from Jammu. Matsya1977; 3: 90-92. 
[23] Normen J R. A History of Fishes. Ernest Bern Ltd., London, 1962; $2^{\text {nd }}$ edition.

[24] Kiran BR. Seasonal Variations in Biochemical Composition of Salmophasia Untrahi (Day) from Bhadra Reservoir, Karnataka. International Journal of Research in Environmental Science 2018; 4(3): 24-29.

doi:http://dx.doi.org/10.20431/24549444.0403003.

[25] Bachan Lal. Biochemical studies in the ovary of Cirrhina mrigala during different maturity stages. Sci. cult.1963; 29: 305-306.

[26] Chaturvedi LD, Joshi BD, Gupta DK. Biochemical composition of some tissues in Heteropneustes fossilis during pre-spawning period. Matsya, 1976; 2: 16-18.

[27] Sivakami S. Studies on the cyprinid fishes of the genus Rasbora Bleeker of Kerala. Ph.D. Thesis, 1981; Kerala University.

[28] Goswami S, Manna K. Nutritional Analysis and Overall Diet Quality of Fresh and Processed (Sun-dried and Fermented) Puntius sophore. Curr Res Nutr Food Sci 2019; 7(2). doi: http://dx.doi.org/10.12944/CRN FSJ.7.2.06.

[29] Çelik U, Oehlenschläger J. Zinc and copper content in marine fish samples collected from the eastern Mediterranean Sea. Eur Food Res Technol. (2005; 220: 37-41. 